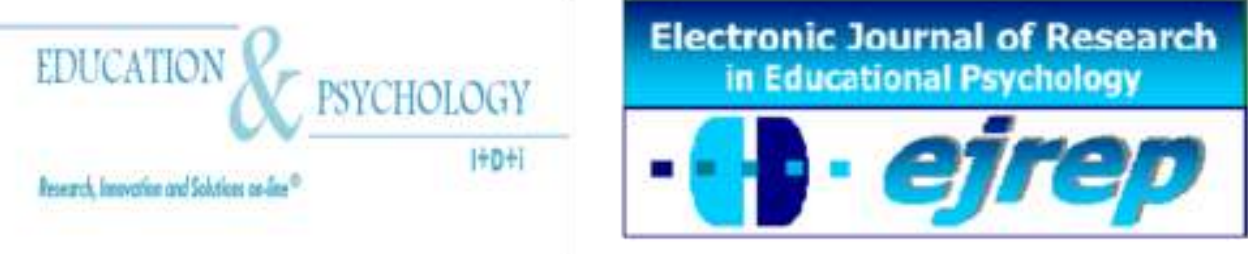

Editorial EOS

\title{
Continuous assessment in a large group of psychology undergraduates
}

\section{Mercè Clariana $^{1}$, Concepción Gotzens, $^{2} \&$ Mar Badia $^{1}$}

${ }^{1}$ Dpt Psicologia bàsica, evolutiva i de l'educació, Univ. Autònoma de Barcelona

${ }^{2}$ Dpt Pedagogia aplicada i psicologia de l'eeducació. Univ. de les Illes Balears

\section{Spain}

Correspondence: Mercè Clariana. Facultat de Psicologia, edifici B, Universitat Autònoma de Barcelona, 08193 Bellaterra. Spain. E-mail: merce.clariana@uab.cat

(C) Education \& Psychology I+D+i and Editorial EOS (Spain) 


\begin{abstract}
Introduction. A continuous classroom assessment method was applied to a higher education course aimed at a large group of educational psychology students at the Universitat Autònoma de Barcelona. Following the Bologna directions and the constructivist model, both declarative and procedural knowledge was taught in the module, and the students were participating in both oral and written activities, individually or in a group, which were at the same time, teaching, learning and assessment activities.
\end{abstract}

Method. The 91 undergraduates of the module were asked to freely answer an anonymous survey at the end of the course. The questions were aimed at providing us with information about the satisfaction level of the students when doing the assessment activities, and about their tendency to procrastinate in our course and in another one with only a final exam as assessment method.

Results. Qualitative and quantitative findings suggest that this sort of teaching and assessment system incorporates many advantages as the students enthusiastically welcomed the opportunity to gain so much theoretical and procedural knowledge at the university, and they stated that this methodology was highly motivating, useful for their learning and that it had help them to curb their procrastination.

Discussion and Conclusion. The results confirm the adequacy of teaching declarative and procedural curricular content at the university and the satisfactoriness of assessing its learning by applying a continuous method. Moreover, the study shows that the students are glad to participate in experiences like this; they get more involved with the course content and enjoy learning this way.

Keywords: Continuous assessment, Declarative content, Procedural content, Case study, Academic procrastination. 


\section{Evaluación contínua en un grupo grande de Psicología Educativa de Barcelona}

\section{Resumen}

Introducción. En un grupo grande de alumnos de Psicología de la educación de la Universitat Autónoma de Barcelona (España) se aplicó un método de evaluación continua de acuerdo con las directrices del Plan Bolonia y el modelo constructivista. Se evaluó tanto el contenido declarativo cómo el procedimental que se habían trabajado en el proceso de enseñanza y aprendizaje durante el curso. Las actividades de evaluación llevadas a cabo durante el curso eran orales y escritas, individuales y en grupo, y al mismo tiempo también eran actividades de aprendizaje, que tenían por objetivo ayudar al alumno a construir conocimiento.

Método. Al finalizar el curso, los 91 alumnos del mismo fueron invitados a participar anónimamente y voluntariamente en el estudio. Contestaron un cuestionario cuyo objetivo era recoger información sobre su nivel de satisfacción en relación al sistema de evaluación del curso. También se administró un test para comparar su nivel de procrastinación académica en nuestro curso y en un curso sin evaluación continua y con examen final cómo único método de evaluación.

Resultados: Los resultados, cualitativos y cuantitativos, sugieren que este tipo de enseñanza y el sistema de evaluación incorporan muchas ventajas ya que los estudiantes recibieron con entusiasmo la oportunidad de construir conocimiento tanto teórico cómo práctico en la universidad. Además, la metodología utilizada fue motivadora y útil para su aprendizaje y los estudiantes señalaron que también les había ayudado a controlar su procrastinación.

Discusión y Conclusión: Los resultados confirman la adecuación de la enseñanza de contenido curricular declarativo y procedimental en la universidad y la pertinencia de evaluar su aprendizaje mediante la participación en actividades continuas durante el curso. Por otra parte, el estudio muestra que los estudiantes aplauden la oportunidad de formar parte de experiencias de este tipo, que se involucren más con el contenido del curso y aprenden a disfrutar del aprendizaje al mismo tiempo.

Palabras Clave: Evaluación continua, contenido declarativo, contenido procedimental, estudio de casos, procrastinación académica. 


\section{Introduction}

The Bologna Process (named after 29 countries signed the Bologna Declaration in June 1999) for the creation of the European Higher Education Area (EHEA) provides the basis to unify higher education in Europe, to ensure international cooperation at this educational level, and to facilitate both staff and undergraduate exchange between the European Union countries. In this context, the European Commission (2010) asserts that one of the four long term objectives of the new EHEA is to improve the quality and efficiency of education and training. This general aim includes, among others features, the need for higher education to teach and aid learning of both the different careers' rationale and the skills and competences required to successfully join the labour market. Thus, in twenty-first century, the university is no longer merely a place to teach and learn theoretical knowledge but also an environment where application and practise are to be aimed for and guaranteed as well. In Trapp's (2008) words and in connection with the teaching of higher education psychology, the university should be a place where the student learns to "think psychologically" and to develop skills transferable to the real world.

On the other hand, all these considerations are not unrelated to the constructivist model in education (Mayo, 2010), which perfectly fits the Bologna premises. It is widely known that this approach conceives students to be active builders of their own knowledge, responsible for their learning process and able to monitor their own outcomes. Many authors have considered and based on these statements when they have planned their lessons. For instance when they have encouraged undergraduates to talk to each other in class in order to build knowledge (Prados, Cubero, \& de la Mata, 2010), they have obtained excellent results.

Thus, accordingly to both the EHEA agenda and constructivism philosophy, the teaching and assessment methods at university should be participative, student centred, based on ongoing educational tasks, organized through problem based learning, and aimed at including, within the learning outcomes, the students' competence to successfully cope with their professional life. 
Teaching methods and type of knowledge

Many recent publications on teaching in university settings present experiences carried out following these directions. For instance, Postle (2009) asserts that teaching and learning applied knowledge, and not just only theoretical one, is a good way to detect, deter and diminish plagiarism and cheating in higher education. In her own words: Assessment which only requires students to "know" is much more open to plagiarism ... than that which requires them to "apply" knowledge or, even further, to "evaluate" it (p. 360). Other authors, such as Coogan and Pawson (2008), propose in-class debating sessions to aid the students to better gain more meaningful knowledge. Moreover, Hugh-Jones and Madill (2008) as well as Tan et al. (2008), focus on collaborative learning with the objective to promote responsibility among students and to develop their ability to learn from each other. And Hulme and Forshaw (2009), to mention one of the most recent publications, highlight practical formative assessment classroom applications based in oral feedback as an alternative to written feedback, because spoken one-to-one advice is found to be the most useful and the most preferred among the students.

\section{Continuous assessment}

In addition, along with a change in the conceptions of the teaching methods, both the Bologna Process (2010) and the constructivist paradigm (Mayo, 2010) recommend the implementation of more continuous assessment approaches. Thus, they emphasize the application of ongoing asynchronous assessment procedures that are tightly linked to everyday classroom activities, among other formulas which will make it easier for each student, to plan and fulfil the instructional objectives.

Many researchers have obtained excellent results when they have applied continuous assessment systems according to these indications. McGann et al. (2008) present an academic summative assessment system which ensures that undergraduates enjoy the learning process, while they develop both job transferable skills and critical thinking. Isaksson (2008) finds that a continuous assessment technique, based on writing "Five minute" essays after every academic lecture, increases students' preparedness and commitment to the course, raises the number of pupils who get high final marks, and proves to be an assessment option which also works as a learning activity as it aids the student to acquire course content while being evaluated. Equally, 
Prescott-Clements et al. (2008) expose the high quality of an assessment method aimed at evaluating medical students in a real job, a method which can assess the learning of procedural knowledge in the first place. As said before, all these publications focus on establishing academic systems capable of enhancing learning and assessing the acquisition of both declarative and practical content at the same time.

\section{Academic procrastination}

Currently, one of the most analysed and studied individual characteristics of undergraduates is academic procrastination, which has been described as the tendency to needlessly and endlessly postpone academic duty. Nowadays this tendency is well known and has been established to be a chronic problem for more than half of post-secondary students (Schouwenburg, 2004; Steel, 2007). Since 1980, when the study of the construct began, academic procrastination has been connected with many other individual features, such as poor use of metacognitive strategies (Howell \& Watson, 2007), academic cheating (Ferrari et al., 1998), lower grades (Moon \& Illingworth, 2005), higher intention-gap dissonance (Dewitte \& Lens, 2000), lower intrinsic learning motivation (Schouwenburg \& Groenewoud, 2001), lower levels of selfefficacy and self-regulation when learning (Klassen et al., 2009), and higher fear to failure in academic settings (Ferrari \& Patel, 2004), to mention only some of the most relevant.

But academic procrastination is not only an individual trait. Many researchers have claimed that this characteristic is tightly linked to the instructional environment, as unfortunately, some educational practices have been found to significantly improve the students' unjustifiable delay. Many publications present results in this direction and today it is widely assumed that academic procrastination is a consequence of both the personality traits of the student and the characteristics of the academic tasks in which this student gets involved (Baumeister et al., 1994; Milgram et al., 1995; Schraw et al., 2007). More specifically, there are authors who maintain that certain assessment conditions, which have been utilized in higher education settings for a long time, such as final exams after a long teaching period or instruction that is only focussed on teaching theoretical knowledge, significantly increase academic procrastination, and beg lecturers to develop and apply more continuous student centred and practicefocussed evaluation methods (Ackerman \& Gross, 2005, 2007). 
Aims of the study

Following both the constructivism and the Bologna directions on teaching and assessing learning and taking into account the current academic procrastination studies, we have carried out research on an educational psychology course aimed at:

1. Teaching both declarative and procedural curricular content.

2. Applying a continuous assessment method based on tasks from everyday teaching and learning activities.

3. Analysing student satisfaction with regard to their learning experience.

4. Comparing the undergraduates' academic procrastination level on this course with the procrastination on other psychology courses which used a single final written examination to evaluate learning.

\section{Method}

\section{Participants}

Initial participants were the 91 undergraduates matriculated in the "Learning and Individual Differences" course at the Universitat Autònoma de Barcelona (Spain, 2010). The course was a not compulsory one offered to last year students, and it is our opinion that they chose it because of the attractiveness of the syllabus, which combined both declarative and procedural knowledge (they are always asking for practice). At the end, the sample was formed by 69 students (76\% of the total), who finished the module and freely answered the anonymous survey. All of them were female (total group: 5 male, $6 \%$; none of them answered the survey).

\section{Procedure}

The tutors gave 12 lectures with a list of articles to be read during the module. In order to continuously evaluate the undergraduates with tasks useful both to asses them and to aid them to learn, we asked the participants to get involved in the following 5 activities throughout the module:

1. PRES DEC. Presentation of the declarative knowledge. Every student chose one of the syllabus' theoretical topics (curriculum, type of knowledge, teaching method, 
teacher burnout, conscientiousness, intelligence, digit ratio, procrastination, class attendance, learning style, learning approaches, career, motivation, and cheating), prepared it from the lectures and readings and presented a summary to the class.

2. PRES PRO. Presentation of the procedural knowledge. First, our students were asked to interview, administer with questionnaires, and give oral psycho educational advice with regard to the course variables to 2 different students: one from secondary school and another from higher education (other than psychology). Secondly, they had to present these experiences to the rest of the class.

3. COMMENT. The students were invited to write 2 in-class reports about their classmates' presentations.

4. MULT CHOICE. A multiple choice exercise with 50 questions and 5 options each was answered by the students at the end of the course. Some of the questions (30\%) had been written by the students themselves in class-time.

5. REPORT. Undergraduates were asked to carry out and write a third psycho educational report, to be delivered to a post-secondary student before entering university. The aim was to give them advice on academic learning and career orientation.

Each one of these 5 activities accounted for 2 points (20\%) of the final mark, as it was thoroughly explained in the syllabus. At the UAB the best mark is 10 points and the lowest 0 . To pass the course the students had to get at least 5 points. With the continuous assessment method our students were expected to plan their own assessment activities, as they could do them (except for the multiple choice exercise) whenever they liked throughout the module (14 weeks). Also, it was possible for them to repeat some of the activities, if they found it necessary, and/or to miss one or two of them, as long as they were able to total at least 5 points at the end of the course.

\section{Materials}

Once all the lessons had finished and the students had been evaluated, we encouraged them to participate in a written anonymous "Continuous Assessment Opinion Survey", which would add an extra 0.5 points to their final qualification. Answering the survey took 15 minutes and included the following variables: 
1. ENJOY. The students were asked to grade each one of the five assessment activities from 10 "I've enjoyed it and it has helped me to learn" to 0 "I didn't like it and it wasn't any help for my learning".

2. BEST. We asked to students to choose the best from the five assessment activities and to comment on it freely.

3. PROC CONT. The undergraduates answered the Procrastination Assessment Scale Students (PASS; Solomon \& Rothblum, 1984) in relation with the continuous assessment system applied to our course.

4. PROC FINAL. They answered the PASS also in relation with a same year university course which had applied a single final test to assess their learning.

5. MARK CONT. They wrote the mark (0 to 10$)$ they had got on our course.

6. MARK FINAL. They wrote the mark (0 to 10$)$ they had got on the course with the final exam.

In both 3 and 4 the PASS the students were administered was a Catalan language version of the questionnaire with a Cronbach's Alpha of .85. As usual, the highest score for PASS was 60 , meaning a high tendency to procrastinate when doing academic work, and the minimum was 12 , meaning the tendency to do the study and class assignments on time.

\section{Data analysis}

With the purpose of analyzing the incidence of the preferred assessment activities, descriptive statistic procedures were carried out for the whole sample. Afterwards, several series of $t$-Tests for paired samples were performed on the results, in order to find out significant differences between the most preferred assessment activity, the case presentation, and the other ones.

In the second part of the data analysis, again a $t$-Test for paired samples was applied, in this occasion to compare both the marks and the procrastination level differences between the continuous assessment solution and the final exam assessment system. Also, bivariate two tailed Pearson correlations were performed, to investigate the connection between the learning outcomes and the procrastination level in the two different assessing conditions, the continuous system and the final exam one. 


\section{Results}

As already stated, 69 students (76\%) willingly answered the "Continuous Assessment Opinion Survey". All of them had participated in all 5 evaluation activities, although that was not a condition to do the survey. From the remaining 22 students on the course, 11 had not written the report ( 2 males), 7 had neither written the report nor presented the theoretical content ( 2 males), and the other 4 had dropped out of the course (1 male). The students' results when grading the adequacy of the assessment activities are shown in Tables 1 and 2. Likewise, Figure 1 represents the undergraduates' preferences when choosing the best activity.

Table 1. Grades given by the students to the five assessment activities from 10 "I've enjoyed it and it has aid me to learn" to 0 "I didn't like it and it has not aid me to learn $(N=69)$

\begin{tabular}{lcccc}
\hline Assessment activity & Mean & SD & Minimum & Maximum \\
\hline PRES DEC & 7.23 & 1.74 & 2 & 10 \\
PRES PRO & 8.06 & 1.77 & 2 & 10 \\
COMMENT & 7.28 & 1.64 & 2 & 10 \\
MULT CHOICE & 7.62 & 1.41 & 4 & 10 \\
REPORT & 7.28 & 1.64 & 2 & 10 \\
\hline
\end{tabular}

Table 2. Paired samples test between the presentation of the procedural content and the other four assessment activities $(N=69)$

\begin{tabular}{lcc}
\hline PRES PRO & $t$ & Sig. (2-tailed) \\
\hline PRES DEC & 8.35 & .000 \\
COMMENT & 2.67 & .012 \\
MULT CHOICE & 1.53 & .130 \\
REPORT & 2.58 & .012 \\
\hline
\end{tabular}




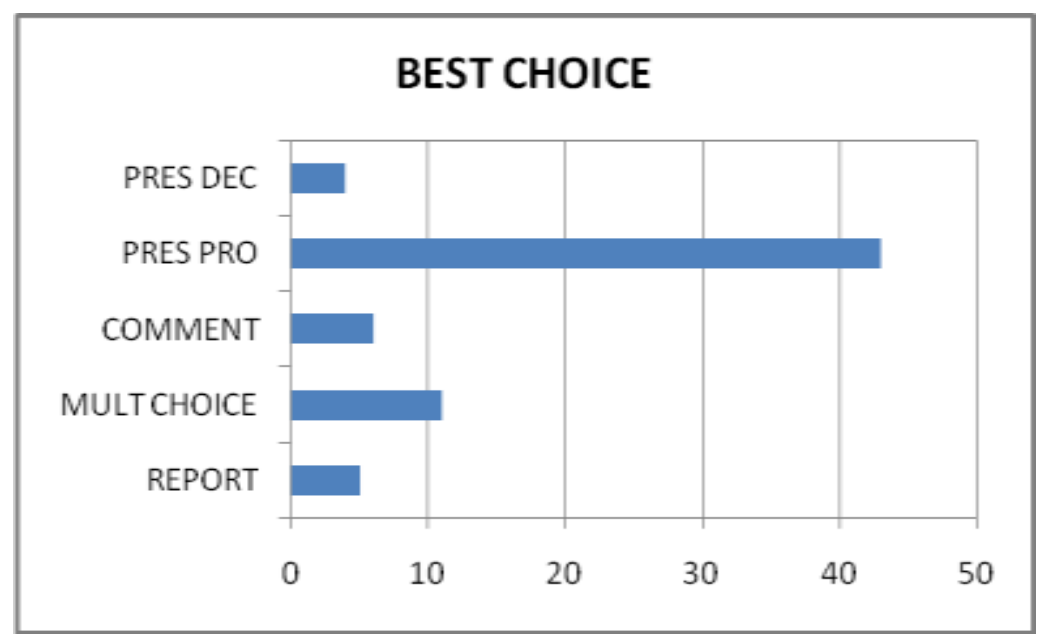

Figure 1. Student's "Best Choice" among the five asessment activities $(N=69)$

Table 1 demonstrates that all the five assessment activities were valued by the students higher than 7 points (over 10). It is clear that they enjoyed doing the activities and found them helpful for their learning. Besides, as can be seen in Figure 1, the most preferred assessment method was the presentation of the procedural content or the case presentation as we used to call it. The students wrote very positive comments about this practice, such as: "It made me feel like a psychologist", "A very practical activity after many theoretical years", "The case presentation made me feel involved with the course", "Helped me to look more in depth at the course declarative content", "The work you do to prepare the case presentation is the best value of this course", "I've noticed my own progress from the first presentation to the second", "I've really enjoyed interviewing my students and giving advice to them", "I will never forget the face of my student when he read my psycho educational report. It is the most gratifying thing I've done at the university".

However, the $T$-test results presented in Table 2 show that the interest the case presentation raised in the students was not significantly higher than that for the multiple choice exercise, aimed at assessing the learning of declarative content. This was quite a remarkable discovery, and the comments confirmed it, because the students said they liked studying the rationale for the multiple choice as much as they liked applying it to real practice. For instance, when focussing on this aspect they wrote: "The multiple choice is a good activity to summarize and integrate all the course content" and "I like it because it obliges me to study and to build theoretical knowledge, which is necessary for practice". 
To end with this first group of results, the less preferred activity was the presentation of the declarative content. The students found it a bit frightening (although they didn't find it frightening to present the cases!), and said things like: "I couldn't sleep the night before my theoretical presentation but in the end I took advantage of it and learnt a lot from the experience" or "I don't like doing a presentation on declarative content because I am very frightened when I have to talk in public. However, having presented with a case and the friendly environment created in class helped me to overcome the problem".

The outcomes for academic procrastination measured by the PASS (Solomon \& Rothblum, 1984), in both continuous and final exam courses, are presented in Tables 3 and 4.

Table 3. Descriptives and paired samples tests between academic marks and academic procrastination (PASS) with the continuous assessment method and the final exam one $(N=69)$

\begin{tabular}{lcccc}
\hline & Mean & SD & $t$ & Sig. (2 tailed) \\
\hline MARK CONT & 8.15 & 1.05 & & \\
MARK FINAL & 6.51 & 1.16 & & \\
PROC CONT & 23.16 & 6.62 & & \\
PROC FINAL & 39.20 & 9.90 & & 8.59 \\
\hline MARK CONT-FINAL & & & -13.24 & .000 \\
PROC CONT-FINAL & & & & .000 \\
\hline
\end{tabular}

Table 4. Correlations between the learning outcomes and academic procrastination (PASS), in the continuous assessment course and in the final exam course

\begin{tabular}{lcc}
\multicolumn{2}{c}{$(N=69)$} & \\
& MARK & MARK \\
& CONT & FINAL \\
\hline PROC CONT & -.64 & \\
PROC FINAL & & -.24 \\
\hline
\end{tabular}

Table 3 shows the undergraduates got higher grades and procrastinated noticeably less in the continuous assessment course than in the final exam module. Both differences are significant $(p=.000)$ so we can state than the students were intensely involved with our course, studied regularly, and kept working for all the 14 weeks without delay. These results obviously agree with what the students emphasized in the survey, as they said the continuous assessment method is a good solution to aid them to overcome procrastination and to feel more implicated in the course. At the end, some of them complained about having had a lot of work, but they 
also realized that working was necessary to learn. In the survey they wrote sentences such as: "Continuous assessment helps me to curb my procrastination, although it is a lot of work", "I am glad to have been working all the time and to avoid the anxiety of the finals", "With continuous assessment you can show all you know without stress", "I like continuous assessment, although it is a lot of work, and I think I will not easily forget the knowledge gained on this course".

On the other hand, with reference to Table 4, the correlation between procrastination and continuous assessment again shows surprising results. Previously, many authors had reported a very moderate relationship $(r=-.19)$ between academic delay and grades (e.g. Moon \& Illingworth, 2005; Steel, 2007), which is similar to the correlation we found between procrastination and grades in the final exam module $(r=-.24)$. Nevertheless, the connection between those two variables in the continuous assessment system is extremely high ( $r=-.64$, explaining nearly $40 \%$ of the variance, which is a great influence). We haven't read other works stating such an important relation between procrastination and grades. Thus, it is our belief that this effect may be connected with the type of content taught and learned in the module (both declarative and procedural), the type of assessment applied to the course (continuous), and/or the type of activities we proposed to the students. Actually, in the survey the undergraduates explained they couldn't procrastinate in our module, it was not possible because they had attractive and beneficial tasks to do every week. Also, this high correlation seems to corroborate that the students who kept working throughout the 14 weeks got high marks in the module, which is what we were intending to provoke. Conversely, in the final exam formula, a cause of the low correlation, studying on time was not found to be so important, as the tendency to delay was only slightly connected with the students' grade in the course.

\section{Discussion}

Our study has shown that psychology undergraduates can genuinely benefit from learning procedural knowledge and participating in a continuous evaluation system. On our course, the students welcomed all five assessment activities we proposed and got high marks at the end of the term.

One of the assessment activities we suggested was a multiple choice exercise. Undergraduates said they loved it, provided it was not the only evaluation task for the course. Also, 
they stated that preparing to sit it helped them deeply to learn the declarative content of the module. That is not unusual because we wrote the exercise following other authors' advice (e. g. McGann et al., 2008; Wilkie et al., 2009): with long questions, enhancing critical thinking, avoiding reproducing definitions, aiming to assess high level knowledge and also to help the students build new connections about the content. We were aware that learning significantly and thinking critically is not an easy activity (Valenzuela \& Saiz, 2010), then we really wanted to help the students doing it in all our lessons.

In addition, we have found a significant difference in academic procrastination between continuous assessment and the final exam procedure, as taking part in the five teaching and assessing activities has proved to prevent the students from unnecessary delay in their academic duties. Furthermore, the students' comments and the exceptionally high correlation between procrastination and grades on our course have shown we succeeded in implementing a continuous study habit, which enhanced the undergraduates' enjoyment as well as their learning results.

Another remarkable finding is the devotion undergraduates showed to case presentation. Solving real cases by academically advising other students involves using some sort of "tacit knowledge" (Hugh-Jones et al., 2009), which is not usually taught and learnt in higher education, and the students certainly appreciated it. Besides, when coping with their cases undergraduates applied problem-solving strategies, which help them to understand the theoretical content better. In the students' own words: "Giving academic advice and presenting my reasons in front of the class helped me to connect all the knowledge that was to be learnt in the course".

A further question to be mentioned here is the importance of sharing the assessment system with the undergraduates, before and while applying it. If they understand the evaluation procedure and its aims they can be more involved in it, decide which activities to do, and create a personal schedule in order to optimize their learning. Also, continuous assessment provides them with continuous feedback on their learning process and helps them to be more selfregulated when building knowledge. And as self-regulation has been stated to be a significant antagonist of academic procrastination (Clariana \& Martin, 2008; Klassen \& Kuzuku, 2009), it is coherent to find that continuous assessment significantly contributes to curb procrastination. Even more, when the students have the habit of keeping working throughout the course, they are closer to not conceiving learning as a one-off duty to be fulfilled but as a deep lifelong 
change in themselves (Peterson et al., 2010), which will undoubtedly lead them to manage their academic achievement better.

In conclusion, it is our viewpoint that for the time being, the Examination Schools will no longer be the only place where undergraduates struggle for a qualification. If nowadays the traditional classroom has widely been transformed into a "learning space" (Khalifa \& Lam, 2002), the assessment activities can no longer be exclusively constrained to a single place that requires the answering of only one test. Instead, they should be stretched to some sort of an "assessment space", intimately linked to everyday instructional activities, involving both declarative and procedural knowledge, requiring oral and written processes, asking both for individual and collaborative work, able to be scheduled, at least to a certain extent, by the students themselves, and offering the chance to be tried again, at least once, with other tuition resources and aid. In other words, the assessment process in higher education should be parallel to the instructional process, composed not only of one exercise but by a heterogeneous group of "learning" activities, flexible enough to accommodate, to a certain extent the personal peculiarities of each learner. Also, assessment activities should be planned with the aim of engaging learners with to content, motivating them to find out, enjoying the process, the same way we usually prepare our teaching and learning proposals.

Thus, in spite of the mass condition of state university (at least in our country), we absolutely agree with the Bologna European Commission (2010) that it is utterly necessary to provide students with the knowledge and skills they will need to use as professionals. In a field like psychology, where new knowledge is continually developed, undergraduates not only need to "think psychologically" as Trapp nicely puts (2008) but to "act psychologically" as well, to be able to succeed in the wide and diverse variety of situations with which they are going to cope in the future.

Teaching both declarative and procedural knowledge on the one hand, and continuously assessing the learning on the other, has proved to be a good beginning in order to reach this aspiration. Now we are thinking of exploring the connection between continuous assessment and other psychological variables, such as the instructional discipline or the tendency to cheat at school, and we would appreciate the chance to broaden the study to more teachers and different university psychology courses. 


\section{Acknowledgements}

This project EDU2009_10651 is funded with support from the Ministerio de Educación (Spain).

\section{References}

Ackerman, D. S., \& Gross, B. L. (2005). My instructor made me do it: Task characteristics and procrastination. Journal of Marketing Education, 27, 5-13.

Ackerman, D. S., \& Gross, B. L. (2007). I can start that JME manuscript next week, can't I? The task characteristics behind why faculty procrastinate. Journal of Marketing Education, 29, 97-110.

Baumeister, R. F., Heatherton, T. F., \& Tice, D. M. (1994). Losing control: How and why people fail at self-regulation. San Diego, CA: Academic Press.

Bologna Process (2010) http://www.ond.vlaanderen.be/hogeronderwijs/bologna/documents/

Clariana, M., \& Martín, M. (2008). Escala de Demora Académica. Revista de Psicología General y Aplicada, 61(1), 37-51.

Coogan, J., \& Pawson, C. (2008). The use of debating as an aid to effective widening participation in psychology. Psychology Learning and Teaching, 7(1), 23-27.

Dewitte, S., \& Lens, W. (2000). Procrastinators lack a broad action perspective. European Journal of Personality, 14, 121-140.

European Commission for the Bologna Process (2010) http://ec.europa.eu/education/lifelonglearning-policy/doc28_en.htm

Ferrari, J. R., \& Patel, T. (2004). Social comparisons by procrastinators: Rating peers with similar or dissimilar delay tendencies. Personality and individual Differences, 37, 14931501 .

Ferrari, J. R., Keane, S. M., Wolfe, R. N., \& Beck, B. L. (1998). The antecedents and consequences of academic excuse-making. Research in Higher Education, 39, 199-215.

Howell, A. J., \& Watson, D. C. (2007). Procrastination: Associations with achievement goal orientation and learning strategies. Personality and Individual Differences, 43, 167-178.

Hugh-Jones, S., \& Madill, A. (2008). Collaborative learning alongside independent project work: A pilot study. Psychology Learning and Teaching, 7(2), 26-33.

Hugh-Jones, S., Waterman, M., \& Wilson, I. (2009). Accessing and understanding the tacit dimensions of assessment. Psychology Learning and Teaching, 8(2), 7-15. 
Hulme, J., \& Forshaw, M. (2009). Effectiveness and feedback provision for undergraduate psychology students. Psychology Learning and Teaching, 8(1), 34-38.

Khalifa, M. \& Lam, R. (2002). Web-based learning: Effects on learning process and outcome, IEEE Transactions on Education 45 (4), 350-356.

Klassen, R. M., \& Kuzucu, E. (2009). Academic procrastination and motivation of adolescents in Turkey. Educational Psychology, 29(1), 69-81.

Klassen, R. M., Ang, R. P., Chong, W. H., Krawchuk, L. L., Huan, V. S., Wong, I. Y. F., \& Yeo, L. S. (2009). A cros-cultural study of adolescent procrastination. Journal of Research on Adolescence, 19(4), 799-811.

Mayo, J. A. (2010). What is constructivism? In J. A. Mayo (Ed.), Constructing undergraduate psychology curricula: Promoting authentic learning and assessment in the teaching of psychology (pp. 33-39). Washington, DC, US: American Psychological Association.

McGann, D., King, S., \& Sillence, E. (2008). Information leaflets: an evaluation of an innovative form of assessment. Psychology Teaching and Learning, 7(1), 19-22.

Milgram, N., Marshevsky, S., \& Sadeh, C. (1995). Correlates of academic procrastination: Discomfort, task aversiveness, and task capability. Journal of Psychology, 129, 145-155.

Moon, S. M., \& Illingworth, A. J. (2005). Exploring the dynamic nature of procrastination: A latent curve analysis of academic procrastination. Personality and Individual Differences, 38, 297-309.

Peterson, E. R., Brown, G. T. L., \& Irving, S. E. (2010). Secondary school students' conceptions of learning and their relationship to achievement. Learning and Individual Differences, 20(3), 167-176.

Postle, K. (2009). Detecting and deterring plagiarism in social work students: Implications for learning and practice. Social Work Education, 28(4), 351-362.

Prados, M. M., Cubero, M., \& de la Mata, M. L. (2010). What structures do university teachers and students use in their classroom interaction? Electronic Journal of Research in Educational Psychology, 8(1), 163-194.

Prescott-Clements, L., van der Vleuten, C. P. M., Schuwirth, L. W. T., Hurst, Y., \& Rennie, J. S. (2008). Evidence for validity within workplace assessment: the Longitudinal Evaluation of Performance (LEP). Medical Education, 42, 488-495.

Schouwenburg, H. C. (2004). Procrastination in academic settings: General introduction. In H. C. Schouwenburg, C. H. Lay, T. A. Pychyl, \& J. R. Ferrari (Eds.), Counseling the procrastinator in academic settings (pp. 3-17). Washington DC: American Psychological Association. 
Schouwenburg, H. C., \& Groenewoud, J. T. (2001). Study motivation under social temptation: Effects of trait procrastination. Personality and Individual Differences 30, 220-240.

Schraw, G., Wadkins, T., \& Olafson, L. (2007). Doing the things we do: A grounded theory of academic procrastination. Journal of Educational Psychology, 99, 12-25.

Solomon, L. J. \& Rothblum. E. D. (1984). Academic procrastination: Frequency and cognitivebehavioral correlates. Journal of Counseling Psychology, 31, 503-509.

Steel, P. (2007). The nature of procrastination: A meta-analytic and theoretical review of quintessential self-regulatory failure. Psychological Bulletin, 133, 65-94.

Tan, W., Lin, S., Yang, Y., \& Zhao, X. (2008). Design on collaborative virtual learning community and learning process visualization. Lecture Notes in Computer Science 5145, 424-433.

Trapp, A. (2008). It is not what we teach but the way we teach it. Psychology Teaching Review, $14(2), 55-57$.

Valenzuela, J., \& Saiz, C. (2010). How Chilean and Spanish university students perceive the cost of thinking critically. Electronic Journal of Research in Educational Psychology, $8(2), 689-706$.

Wilkie, R. M., Harley, C., \& Morrison, C. (2009). High-level multiple choice questions in advanced psychology modules. Psychology Learning and Teaching, 8(2), 30.36. 